\title{
Social Media Is Redistributing Power
}

\author{
Nian Yan \\ Kaili University, Kaili, China \\ Email: near511@163.com
}

How to cite this paper: Yan, N. (2021). Social Media Is Redistributing Power. Open Journal of Social Sciences, 9, 107-118. https://doi.org/10.4236/jss.2021.96010

Received: May 7, 2021

Accepted: June 13, 2021

Published: June 16, 2021

Copyright (c) 2021 by author(s) and Scientific Research Publishing Inc. This work is licensed under the Creative Commons Attribution International License (CC BY 4.0).

http://creativecommons.org/licenses/by/4.0/

\begin{abstract}
Social media has become an important part of people's daily life and the whole society, which not only transforms forms of communication, but also has the ability to redistribute power by transforming the relationship between governments and citizens, by giving citizens more opportunity to participant political, spreading democracy awareness, having power to contend against the unfair social events and surveilling the behavior of governments. It also challenges the position of traditional media and democratizes media and information. The aim of this essay is to explore how social media can redistribute power. The main method used is case study, along with documentary analysis, statistical analysis, and personal observation. It is divided into four sections. The first section will briefly discuss how social media transforms the forms of communication; the power of social media shifting in political sphere will be discussed in the second section; the third section will explore the power shifted and redistributed between social media and traditional media; and the dark side of the over powered social media will be discussed in the fourth section.
\end{abstract}

\section{Keywords}

Social Media, Redistributing Power, Traditional Media

\section{Introduction}

Over the past few years, social media has become an important part of people's daily life and even to the whole society. According to Kaplan \& Haenlein (2010: p. 61), social media is a platform which allows users, and groups of users, to create and exchange content; it can be defined as "a group of Internet-based applications that build on the ideological and technological foundations of Web 2.0". The applications of social media include Facebook, Twitter, Tumblr, Microblog and WeChat. The users of social media are increasing sharply over the past five years, the number of social media users is over 3.6 billion last year 
(2020), and a number is projected to increase to almost 4.41 billion in 2025 (Social Media \& User-Generated Content, 2021). Social media has low requirements for everyone; it can be used anytime, anywhere and via any online electronic device, including computer, laptop and cell phone. People can use social media to communicate with each other as long as they want, which breaks the restriction of time and space. Social media is changing the traditional ways of people communication; people no longer need to talk with others face-to-face or in a limited space; it helps people become more sociable and provides numbers of unexpected chances. What's more, social networking has not only mediated communication in countless ways, but the ways people communicate and even the ways they talk and think about communication are also changing as a result. What's more, social networking has not only "mediated communication in countless ways", but the ways people communicate and even the ways they talk and think about communication are also changing as a result.

Besides, social media not only transforms forms of communication, but also has the ability to redistribute power by transforming the relationship between governments and citizens, by giving citizens more opportunity to participate in politics, spreading democracy awareness, having power to contend against unfair social events and surveilling the behavior of governments; it also challenges the position of traditional media and democratizes media and information.

\section{The Power of Social Media Shifting in Political Sphere}

\subsection{Redistribute the Power among Governments and Citizens}

Social media has not only changing the ways people communication, it also has ability to redistribute the power, especially among governments and citizens. Nowadays, with the development of social networking, the power of changing the world is not only the leaders, according to a study from HAVAS GLOBAL COMMS (2013), the single greatest "agent of change" is "the people, empowered by social media". Social media effect on political sphere by shifting who controls the information, how to distribute that information and how it be changed.

Before the social media era, people are just passive accept the information from government, their opinions are not easy to express. In the traditional media world, it only can use mass media as the way to carry out one-to-many information. Corporations, governments or other groups controlled the information conveyed with laws or sometimes "simply by owning the means of distribution" (Bennett, 2011). The owner of the information has the ability to control what the information is transmitted and how the information is framed.

\subsection{User Driven Era}

In contrast, the social media is a user driven era, user has greater control of the information. Public can decide the content of information and give the opinion to each other timely. It can convey information more effective and "engaging its audience" Gainous \& Wagner, 2014: p. 6). Since people can obtain and access 
information easier, they may have chance and glad to involve the political area. Academic research has found that people who consume more social media have a greater probability of being "civically and politically engaged across a variety of measures" (Wihbey, 2015). Social media has no doubt influence the political sphere and the population of people involved has increased as time passes by. In 2008, there were about 1.5 million "election-related" tweets while in 2012, the number has become 31 million (Jeffers, 2013).

\subsection{Made a Fundamental Shift in the Political Environment}

Social media has made a fundamental shift in the political environment, that is, not just change the way people interact with each other, access and obtain information, but "ultimately use this information to choose who governs", which has changed the existing media landscape and "structures guiding political communication" (Gainous \& Wagner, 2014: p. 3). The 2008 American presidential election, Obama had got most support from social media, according to Soumitra Dutta and Matthew Fraser (2008), Obama had more than 2 million American supporters on Facebook and could count on more than 112,000 supporters "tweeting" to get him elected. While the McCain, just has over 600,000 on Twitter. Moreover, during the 2012 Democratic National Convention, President Obama's nomination acceptance speech generated a great number of social media users discussed. When the speech was being delivered, there are over 50,000 tweets about Obama that were happening per minute. The three-day event has generated nearly 10 million tweets that were directly relevant. Obama has become the first one who uses social media to run for president and got success.

\subsection{Social Media and Social Movement}

Moreover, social media has given people more power to conflict and play important role in promoting the social movement, they can use social media to initiative control the information. According to Morozov (2011), "the revolutionary potential of grassroots movements" and the "long-term power of politicisation of social media" should never be ignored. There are many examples in the history, one of them is the famous "Twitter revolution" in Iran 2009, the major Iranian cities, particularly Tehran and Isfahan witnessed street protests to complain about the "allegedly fraudulent" presidential elections after the incumbent candidate Mahmoud Ahmadinejad beat opposition candidate Mir-Hossein Mousavi (Kamalipour, 2010). Social media particularly Twitter has played an important role in this revolution since the Iran government's information blackout, the traditional media has been controlled and messages could not be sent. While Iranian use the Internet, the social media to communicate with outside and report all the events attracted world's attention and posed pressure to Iran government. Iran Twitter revolution is the first major world event "broadcast worldwide almost entirely via social media” (Keller, 2010). Fatemeh Keshavarz, an Iranian professor and activist who runs a blog called "Windows on 
Iran," said that social media has made the Iranian citizens feel empowered, "it also helped the western world, particularly the United States, to see that the Iranian society was far from the machines of ideology blinded by faith and ready to blow up the world" (El-Nawawy \& Khamis, 2012).

The Arab Spring from 2010 to 2011, a revolution wave of protest and demonstration, in this revolution, social media has played a central role to put it forward. According to Howard et al. (2011), in Arab Spring, social media has shaped political debates and helped spread democratic thought through the internet. Social media exposed the political corruption online so that create discontent among people and as a useful tool for people to communicate with outside and reported the up-to-date situation. CNN journalist Octavia Nasr describes the social media was a megaphone for the Arab Spring, which gave this revolution a major boost, served as the platform where "activism thrived, ideas were shared along with news, updates and videos; all things the mainstream western media had totally ignored in previous years" (Tynes, 2012).

Smelser (1962) in his Theory of Collective Behavior put forward value-added theory, only when the six elements continuous added can lead to social movement: "Structural conduciveness"-the structure of the society, "Structural strain"- there must be a strain on society caused by the factors like social system and create dissatisfaction of public, "Generalized belief" - understood by the participants about the issues, "Precipitating factors"-blasting fuse of the event happens, "Mobilization for action" and "Operation of social control". These social movements have satisfied this frame, take Arab Spring as an example, actually it happens under the institution factor, the accumulation of social contradictions, trigger by the self-burning event in Tunisia, mobilized by the Internet and social media has boosted this event. When the control of government to society has declined, the social movement could happen. Therefore, the political power of social media mainly lies in the influence of mobilizing in social action. There are two aspects of social media effect on social action, first, it shapes public opinion, thus stimulates public mood, forms the resonance psychological, then enhances cognition for collective action. Second, forms the informal organization network, thus providing collective action the organization foundation and coordination mechanism (Cao et al., 2013). Social media spreads awareness to express people's general opinion online so that acquire their common cognition and then according to the movement leader's appeal to get a large group of supporters. It also uploads up-to-date news and videos to stimulate much more public emotions even to abroad so that get greater support. Gladwell and Shirky (2011) argue that social media "facilitates the online organisation of none-institutionalised" groups of people; making this "easier, quicker and cheaper that it could have been done without these platforms".

\subsection{A Useful Tool to Monitor Government}

In addition, social media also can be a useful tool to monitor government and 
report corruption, one of the famous example is Chinese "Brother Wristwatch", a provincial Chinese official Dacai Yang. A photo showing his smile standing on the road and wearing a luxury wristwatch that he could not possibly afford on his public servant's salary has been spread on Weibo, and then a user in Weibo had found and reported several photos which he has worm more than 5 different pieces of luxury wristwatch. After public impeached and department investigation, the prosecutors concluded that Yang had been unable to explain "the provenance of $£ 527,000$ in dubious assets and last month he pleaded guilty to taking $£ 26,000$ in bribes” (Kaiman, 2013). Besides, in the same year, two months later than "Brother Wristwatch" event, another Chinese official Zhengfu Lei was sacked after his sex tape leaked online.

The network anti-corruption is a new concept in Eastern Europe and Central Asia to prevent and fight corruption (OECD, 2015). It uses the Internet especially social media as a platform to report the corruption of government. The deputy of Anti-Corruption Research Center Gao Bo said that social media helps make "ordinary people's voices heard in the anti-corruption campaign, and makes supervision easier and more cost-effective" (CNTV, 2013). The development of the Internet and social media is making the difference to challenge the corrupt officials.

\subsection{Dominate Media and Pluralist Media}

In discussion of the power of media, McQuail (2010) in his Mass Communication Theory put forward two modes to describe: dominate media and pluralist media. The first one is on behalf of some powerful institutions, controlled by small group of powerful interests; the ownership of the media management mode is the centralized control, and audience accept the view has been constrained and passive, lack of critical response. The traditional media are more like this mode. While the pluralist mode is "nearly every respect, the opposite, allowing for much diversity and unpredictability". It has lots of independent media, no elite control, more democratic. This mode is idealized. Obviously, social media are much more like this mode, which gives citizens more power to break the traditionally established equilibrium between the government and social order. The challenge of social media brings to government is not technology but the pluralist media mode.

\subsection{The E-Government}

The E-Government has been established to enhance the relationship between governments and citizens. The OECD (2013) defined the E-Government as the "use of information and communication technologies, and particularly the Internet, as a tool to achieve better government". It helps improve efficiency in government, enhance the quality of government service. Government used social media like the instant message tool Twitter to get contact with citizens, they can use it to announce special events and via the feedback from citizens' comments 
to check how this event is perceived by citizens. This can help improve "policy making and service delivery" (Bonson et al., 2012). E-Government provides a platform which public can access political information easily express political opinion and discuss political issues, on the hand also enable government's control efficiently.

In a word, social media has opened a door to public to access the government information, discuss political opinion and monitor government officials' behavior. Public can control the information, guide the public opinion and mobilize large groups of support, have the initiative of information. The potential of social media lies mainly in their support of "civil society and the public sphere" (Shirky, 2011). Through get and spread the "shared awareness" on social media, which "reshapes the public sphere" and "challenge the government's monopoly on public speech" (op cit, 2011). Those are the ways how social media redistributing and shifting the political power between governments and citizens. As for government, how to use social media effectively and improve the capacity to shape public opinions is a question well worth studying at present.

\section{The Power Shifting between Social Media and Traditional Media}

Social media not only redistribute the power between governments and citizens, it also shifted the power between itself and the traditional media through present better when report certain news, challenge the position of traditional media and democratized media and information.

\subsection{The Citizen Journalist}

First, with the development of social media, here comes a new concept, the citizen journalist, which is a group by general public reporting news use the means of internet especially social media to spread it online. When reporting disaster and breaking news, under certain situations, citizen journalists do much well than those who work in print or TV news. Since lack of gatekeeper and has no constrained by organizations or certain particular rules, citizen journalism can report things as they want which traditional journalists are under pressure cannot do that. What's more, there is no space and time limitation for citizen journalism, so it is easy to report news. Newman (2009) notes that the news in social media is "broken" and sometimes "runs hours ahead" of traditional news organizations. For instance, the first report of 2008 Wenchuan earthquake in Sichuan province China was by a citizen journalist who used social media to post it online, about one minute after earthquake happen, there was a post online, "Very urgent!!!! Where has a massive earthquake occurred!".

There are also some other examples, the 2004 Indonesia tsunami, the first hand reports were from citizen journalist, they have filmed lots of digital photographs, mobile snapshots etc. "Most images and video footage provided by amateurs" (Prentoulis, 2014); the death of Osama Bin Laden is first been reported on 
Twitter; the death of Whitney Houston reported first on Twitter before the Associated Press confirmed the incident 55 minutes later (Newman, 2009); the Haiti earthquake, first reported on Twitter after seven minutes while CNN live coverage it after 17 hours (Dube, 2012).

Citizen journalism has occupied a large advantage on advantageous time and space efficiency to report news which traditional journalism hard to compare with. What's more, to some extent, citizen journalists are more useful in reporting some news which has been omitted by traditional media since they are constrained by organizations or certain particular rules. Therefore, social media has become a advanced platform for people to get to know the news in breaking and emergency events. According to Morejon (2012), over 50\% of people acquire breaking news on social media rather than any other official news sources.

\subsection{The Challenge of Traditional Media}

Besides, the social lead position of traditional media in marketers also has been challenged. In the past, traditional media once bring the great benefit to marketers, while nowadays, the "fragmented and dwindling" audiences, as well as "comparatively cruder metrics" has transformed their focus to the digital networking, the social media area. The traditional media has suffered a greatest loss of interests (Advertising \& Marketing, 2013).

Second, as mentioned before, people get news mainly from the traditional media like newspaper, TV and radio before web 2.0. While when entering the Web 2.0, social media era, people not only rely on traditional media as their door to know the word, the monopoly and position of traditional media are declined. Social media has become another most source for people to acquire information, especially for young people. According to Pew Research (2021), 86\% of Americans get news online from digital devices. Social media has opened another window for them or they can participate in it directly. According to a report on the news industry in the Economist (2011), the rise of social media means that news is "no longer gathered and turned into a news exclusively" by journalists but emerges from "an ecosystem in which journalists, sources readers and audiences exchange information". As a result, social media not only as a "vehicle for disseminating democracy" (Poster, 1997) it also has democratized the media so that lead to the authority and the sway of traditional media has declined. Bowman and Willis (2003: p. 47) argue that a "democratized media challenges the concept of the institutional press as the privileged, exclusive, trusted informed intermediary of the news".

What's more, the agenda setting of traditional media has also declined, people have more alternative ways to acquire information and express their opinion. According to Gillmor (2004), traditional media are lost the control of the news agenda since social media has empowered even ordinary people to produce news independently. "They were becoming valued news outlets that direct their read- 
ers to information of interest and help them filter, simplify and clarify news". Therefore, to some extent, social media has posed a great threat to traditional media, the power of each has already been shifted and redistributed.

\section{The Dark Side of Social Media Power}

\subsection{Privacy and Information Freedom Problem}

There is no doubt that the power social media has many benefits to the society, while it also has its dark side and some of them even very dangerous. The power of social media even can be horrible to some extent. The first thing that should be noticed is the privacy and information freedom problem. Since social media lack of the gatekeeper and has low requirement, information is totally freedom in the online world, no information keeper, no controller. A report (Privacy Rights Clearinghouse, 2010) states that "social network can change its privacy policy at any time without a user's permission". Social psychologist James Pennebaker, of the University of Texas-Austin, states that privacy is a big issue for the research world, "A bunch of researchers have access to everybody's posts and Facebook is built on what's yours is private" (Jayson, 2014). A Lancaster University $\mathrm{PhD}$ student argues that the social media users and their personal information are like the products.

The social network site is unsafe, while the people who use social network is more dangerous. Everyone can use social media presents a greater risk of people's privacy being exposed online which means the reputation is vulnerable. For example, the "dog poop girl" event in South Korea, a young woman takes a dog with her on a train subway, the dog poops but she refuses to clean it up despite been told by other passengers. Someone happens to be there with a camera and then takes a picture and posts it in the popular blog. Then, the story goes viral, it spread online so that the whole world knows about it. And the young woman is publicly shamed. Reportedly, it has led the young woman to drop out the university and she suffered from mental illness (Bernal, 2014). Spread it online without the permission or cover the woman's face, exposure this young woman on the public lead to the cyber-violence in this rude action. It has already violated other's privacy and damaged her reputation.

Furthermore, the social media information freedom not only affects individuals but also poses threat to government. In web2.0, people have more free access to speak online, everyone can report the fact and their opinions online. It, however, poses a threat to government under certain circumstances. According to Bertot et al. (2012: p. 33), the Federal Agency requires the policies that should offer appropriate security controls to make sure online information is "resistant to tampering, to preserve accuracy, to maintain confidentiality as necessary, and available".

\subsection{The Risk of Committing Crimes}

Second, social media can be used as a platform to spread democracy, it also can 
become extremists' tools even for committing crimes. The director of Britain's Government Communications Headquarters, Robert Hannigan emphasized, technology services especially social media "have become the command-and-control networks of choice for terrorists". Just in a single day in 2014 summer, ISIS supporters have sent out 40,000 tweets, and supporters often "repetitively tweet specific hash tags at particular times of day to maximize message trending" (Wiktorowicz \& Amanullah, 2015). According to Declan Harvey (2015), the Islamic State extremists are using "aggressive online social media campaigns" to recruit young people from the UK. The deadly terrorist attacks on Paris in January 2015, the social media networks also have been used as terrorists' tool to spread their "propaganda and recruit fighters as well as copycats actively" (Dubois, 2015).

These extremists are using social media to expose their idea to upload powerful contents, pictures and videos about their purpose to persuading people and then finish their recruits. In other words, more than being an "ideological battleground, social media now act as the backbone of extremists' organizations" (op ict, 2015). According to Sunstein (2013), the terrorism itself can arise not because people are "isolated, poor or badly educated", but because they are "part of tightly knit networks in which hateful ideas travel quickly". Social network, therefore, has become a useful platform in transforming these ideas and facilitating the action. Shirky (2011) specifies that "social media increase shared awareness by propagating messages through social networks", the "shared awareness" can be either optimistic or negative. How to use it correctly and control who and the purpose of using it are essential.

\section{Conclusion}

This essay has explored the enormous power of social media and how social media are redistributing the power. With the development of technology and information society, social media has become an indispensable part of the world. It not only changes the way how people are communicating, enlarge friends circle and improve communication skills; but also has a great ability to shift and redistribute power, and has a deep impact on society. Social media redistributes the political power among governments and citizens, gives citizens more access to attend politics, obtains political information, discusses political opinion, controls information initiatively, boosts social movement and reports corruption; and poses threat to traditional media by shifting the social leading power among them. The enormous power of society promotes the forward of society but also can cause great damage to society. Social media is a new uprising power in the world, which still has numbers of problems. Only tackling these issues correctly can the power of social media be used in the right way.

\section{Conflicts of Interest}

The author declares no conflicts of interest regarding the publication of this paper. 


\section{References}

Advertising \& Marketing (2013). In 2013, Mobile, Social Lead Shift from Traditional Media to Digital.

https://www.emarketer.com/Article/2013-Mobile-Social-Lead-Shift-Traditional-Media -Digital/1009677

Bennett, W. (2011). News: The Politics of Illusion (9th ed.). New York: Longman.

Bernal, P. (2014). Rethinking Reputation.

https://learn.uea.ac.uk/bbcswebdav/pid-1351945-dt-content-rid-1775591 1/courses/PP LMM09Y-14/Rethinking\%20Reputation\%202014.pdf

Bertot, J. C., Jaeger, P. T., \& Hansen, D. (2012). The Impact of Polices on Government Social Media Usage: Issues, Challenges, and Recommendations. Government Information Quarterly, 29, 30-40. https://doi.org/10.1016/j.giq.2011.04.004

Bonson, E., Torres, L., Royo, S., \& Flores, F. (2012). Local E-Government 2.0: Social Media and Corporate Transparency in Municipalities. Government Information Quarterly, 29, 123-132. https://doi.org/10.1016/j.giq.2011.10.001

Bowman, S., \& Willis, C. (2003). We Media: How Audiences Are Shaping the Future of News and Information (pp. 1-65). Reston: The Media Center at the American Press Institute.

Cao, F., Li, H. M., \& Peng, Z. C. (2013). The Political Power of Social Media. https://opinion.m4.cn/2013-01/1197881.shtml

CNTV (2013). Weibo: An Eye on Corruption. https://www.china.org.cn/china/NPC CPPCC 2013/2013-03/11/content 28201650.htm

Dube, N. (2012). The Future of Traditional Journalists in Social Media Era: Towards Changing Roles and Understandings.

https://www.academia.edu/2509138/The Future of Traditional Journalists in Social Media era Towards changing roles and understandings

Dubois, D. (2015). The Dark Side of Social Media: Did Facebook, Twitter and YouTube Kill Charlie?

https://knowledge.insead.edu/blog/insead-blog/the-dark-side-of-social-media-did-face book-twitter-and-youtube-kill-charlie-3804

Dutta, S., \& Fraser, M. (2008). Barack Obama and the Facebook Election. https://www.usnews.com/opinion/articles/2008/11/19/barack-obama-and-the-facebook -election

El-Nawawy, M., \& Khamis, S. (2012). Political Activism 2.0: Comparing the Role of Social Media in Egypt's "Facebook Revolution" and Iran's "Twitter Uprising”. https://www.cyberorient.net/article.do?articleId=7439

Gainous, J., \& Wagner, K. M. (2014). Tweeting to Power: The Social Media Revolution in American Politics. Oxford: Oxford University Press. https://doi.org/10.1093/acprof:oso/9780199965076.003.0001

Gillmor, D. (2004). We the Media: Grassroots Journalism by the People. Sebastopol, CA: O’Reilly Media Inc.

Harvey, D. (2015). How Islamic State Extremists Use Social Media to Recruit. https://www.bbc.co.uk/news/newsbeat-31574846

HAVAS GLOBAL COMMS (2013). 1 in 3 Millennials Uses Social Media to Change the World for the Better.

https://dare.havas.com/news-archive/community-and-citizenship/

Howard, P. N., Duffy, A., Freelon, D., Hussain, M., Mari, W., \& Mazaid, M. (2011). Opening Closed Regimes: What Was the Role of Social Media during the Arab Spring 
Project on Information Technology and Political Islam. Seattle: Department of Communication, University of Washington. https://doi.org/10.2139/ssrn.2595096

Jayson, S. (2014). Social Media Research Raises Privacy and Ethics Issues. https://www.usatoday.com/story/news/nation/2014/03/08/data-online-behavior-resear $\mathrm{ch} / 5781447$

Jeffers, D. (2013). How Social Media Has Changed Politics: It's Not Just Tactics. https://thesocialmediamonthly.com/how-social-media-has-changed-politics-its-not-jus t-tactics

Kaiman, J. (2013). China's “Brother Wristwatch” Yang Dacai Jailed for 14 Years for Corruption. The Guardian.

https://www.theguardian.com/world/2013/sep/05/china-brother-wristwatch-yang-daca i-sentenced

Kamalipour, Y. (2010). Introduction. In Y. Kamalipour (Ed.), Media, Power, and Politics in the Digital Age: The 2009 Presidential Election Uprising in Iran (pp. XVII-XXII). Maryland: Rowman \& Littlefied Publishers, Inc.

Kaplan, A. M., \& Haenlein, M. (2010). Users of the World, Unite! The Challenges and Opportunities of Social Media. Business Horizons, 53, 59-68.

https://doi.org/10.1016/j.bushor.2009.09.003

Keller, J. (2010). Evaluating Iran's Twitter Revolution. https://www.theatlantic.com/technology/archive/2010/06/evaluating-irans-twitter-revo lution/58337

Gladwell, M., \& Shirky, C. (2011). From Innovation to Revolution: Do Social Media Make Protests Possible?

https://www.foreignaffairs.com/articles/67325/malcolm-gladwell-and-clay-shirky/from -innovation-to-revolution

McQuail, D. (2010). Mass Communication Theory(6th ed.). London: SAGE Publications.

Morejon, R. (2012). How Social Media Is Replacing Traditional Journalism as a News Source.

https://www.socialmediatoday.com/content/how-social-media-replacing-traditional-jo urnalism-news-source-infographic

Morozov, E. (2011). On This Question, "Picking a Fight with Clay Shirky”. Net Effect, January 15, 2011.

Newman, N. (2009). The Rise of Social Media and Its Impact on Mainstream Journalism. Oxford: Reuters Institute for the Study of Journalism.

OECD (2015). The Anti-Corruption Network. https://www.oecd.org/corruption/acn

Pew Research (2021). More than Eight-in-Ten Americans Get News from Digital Devices. https://www.pewresearch.org/fact-tank/2021/01/12/more-than-eight-in-ten-americansget-news-from-digital-devices

Poster, M. (1997). Cyberdemocracy: Internet and the Public Sphere. In D. Porter (Ed.), Internet Culture (pp. 201-218). London: Routledge.

https://doi.org/10.4324/9780203948873-12

Prentoulis, M. (2014). The Death of Journalism.

https://learn.uea.ac.uk/bbcswebdav/pid-1352593-dt-content-rid-1777638 1/courses/PP LMM09Y-14/The\%20Death\%20of\%20Journalism\%20MCSMarina\%281\%29.pptx

Shirky, C. (2011). The Political Power of Social Media: Technology, the Public Sphere, and Political Change. Foreign Affairs, 90, 39-40.

Smelser, N. J. (1962). Theory of Collective Behavior. New York: Free Press. https://doi.org/10.1037/14412-000 
Social Media \& User-Generated Content (2021). Statista.

https://www.statista.com/statistics/278414/number-of-worldwide-social-network-users

Sunstein, C. R. (2013). Column: Social Capital Has a Dark Side: It Can Aid and Abet Extremism. Vnews.

https://www.vnews.com/home/7910643-95/column-social-capital-has-a-dark-side-it-ca n-aid-and-abet-extremism

The Economist (2011). The People Formerly Known as the Audience. https://www.economist.com/node/18904124

Tynes, N. (2012). Octavia Nasr: Social Media Were a "Megaphone" for the Arab Spring. https:/ijnet.org/en/blog/octavia-nasr-social-media-were-megaphone-arab-spring

Wihbey, J. (2015). How Does Social Media Use Influence Political Participation and Civic Engagement? A Meta-Analysis.

https://journalistsresource.org/studies/politics/digital-democracy/social-media-influen ce-politics-participation-engagement-meta-analysis

Wiktorowicz, Q., \& Amanullah, S. (2015). How Tech Can Fight Extremism.

https://edition.cnn.com/2015/02/16/opinion/wiktorowicz-tech-fighting-extremism/ind ex.html 